\title{
Lactococcus lactis caused septicemia in total parenteral nutrition dependent child with ultra-short bowel syndrome \\ Case report
}

A.Rudzroga ${ }^{1,2}$, I.Kaze $^{3}$, I.Pukite ${ }^{3}$

${ }^{1}$ Children's Clinical University Hospital, Clinic of Pediatrics, Riga, Latvia

2University of Latvia, Pediatric resident, Riga, Latvia

${ }^{3}$ Department of Pediatric gastroenterology, Clinic of Pediatrics, Children's Clinical University Hospital Riga, Latvia

\section{BACKGROUND}

Lactococcus does not normally colonize human tissue and is classified as a nonpathogenic. Lactococcus lactis is a spherically-shaped, facultative anaerobe, gram-positive, lactic acid bacterium widely used in industrial production of the fermented dairy products. [1] Lactococcus lactis is a commonly used probiotic to treat gastrointestinal symptoms such as diarrhea. [2] There are few reports where the bacterial infection has been caused by Lactococcus species in children, and the mechanism of the infection is unclear. Bacterial translocation from the gut is the most probable mechanism [3;4]

We report a case of a 3-year-old girl with the ultra-short bowel syndrome, duodenocoloanastomosis, Broviac catheter, portal hypertension and who is on a long-term home parenteral nutrition. Over the time, she has developed parenteral nutrition inducedcholestasis with cholelithiasis and recurrent pancreatitis.

The girl was born at $24-25^{\text {th }}$ gestation week (gravida 2, para 1) with a birth weight $750 \mathrm{~g}$. On the $9^{\text {th }}$ day of life her health condition deteriorated: she was presented with abdominal distention and decreased intestinal peristalsis. Acute abdominal surgery was performed - with a massive necrotic small intestine resection $(1 \mathrm{~cm}$ below the ligamen of Treitz including the ileocecal valve to colon ascendens) and a formation of duodenocoloanastomosis. From the first days of her life, the girl is parenteral nutrition-dependent. Moreover, until the age of 2 years and 8 months, she had been permanently hospitalized. However, currently she lives in the orphanage and is one of the participants of the Home Parenteral nutrition program and she has been implanted a Broviac type catheter.

At this episode, the girl had fever of $38^{\circ} \mathrm{C}$ two days before administration to the hospital and no other symptoms. At the Emergency Department, first dose of Cefuroxime was given as for a patient with an unknown bacterial infection (CRP $76.57 \mathrm{mg} / \mathrm{L}$ ). Blood cultures from both arms and a Broviac type catheter were taken. At the Pediatric Gastroenterology Department, the treatment was changed to Pipercallinum-Tazobactamum as for a high risk patient of catheter-related infection. At the $3^{\text {rd }}$ day of administration, fever persisted and CRP increased to $112 \mathrm{mg} / \mathrm{L}$, the positive blood culture was identified as Lactococcus lactis without antibacterial sensitivity. As a result of the identification, the antibacterial treatment was changed to Vancomycine following the cases from medical research publications. Afterwards, only one fever episode was observed and Vancomycine was given for 14 days. Control blood cultures were taken on the $18^{\text {th }}$ day of hospitalization, all negative. In the retrospective analysis, it was found out that she has been given some unknown probiotics contrary to the recommendations.

\begin{tabular}{|c|c|c|c|c|c|}
\hline $\begin{array}{c}\text { Day } \\
\text { of hospitalizaton }\end{array}$ & $1^{\text {st }}$ day & $1^{\text {st }}$ day & $3^{\text {rd day }}$ & $4^{\text {th }}$ day & $9^{\text {th }}$ day \\
\hline Antibacterial agent & Cefuroxime & $\begin{array}{l}\text { Piperacillinum/ } \\
\text { Tazobactamum }\end{array}$ & Vacomycinum & & \\
\hline CRP (mg/l) & 76.57 & & 112.97 & & 7.51 \\
\hline $\begin{array}{l}\text { Fever } \\
\text { (episodes per day) }\end{array}$ & $2-3$ & $1-2$ & 1 & 0 & 0 \\
\hline Blood culture & & & $\begin{array}{c}\text { Lactococcus } \\
\text { lactis }\end{array}$ & & \\
\hline
\end{tabular}

\section{LEARNING POINTS/DISCUSSION}

1. The case report suggests that we should be aware of mostly non-pathogenic bacteria causing serious infection in patients who are immunocompromised or who have a longterm intravenous catheter.

2. Probiotic use for patients with a long-term central venous catheter is prohibited due to a high risk of bacterial translocation from the gut.

3. A patient with a long-term catheter and fever episodes of unknown cause always needs to be regarded as a patient with catheter-related infection, immediate empiric antibacterial treatment must be administered.

REFERENCES

1. Kenneth Todar, PhD (2008-2012) Lactococcus lactis: nominated as the Wisconsin State Microbe. Todar's Online Textbook of bacteriology. 2008-2012

2. Nuryshev M.Z., Stoyanova L.G., Netrusov A.I. (2016). New Probiotic Culture of Lactococcus lactis ssp. lactis: Effective Opportunities and Prospects, J Microb Biochem Technol 2016, 8:4 (DOI: 10.4172/19485948.1000299)

3. Karaaslan A., Soysal A., Kepenekli Kadayifci E., Yakut N., Ocal Demir S., Akkoc G.,Atıcı S., Sarmıs A.,Ulger Toprak N.,Bakır M. (2016) Lactococcus lactis spp lactis infection in infants with chronic diarrhea: two cases report and literature review in children. J Infect Dev Ctries 2016; (10(3):304-307. doi:10.3855/jidc.7049)

4. Overturf GD (2006) Focal bacterial infections: necrotizing enterocolitis. In: Remington JS, Klein Jo, Wilson

$C B$, editors. Infections diseases of the fetus and newborn infant. Philaelphia: Elsevier Saunders. 358-363 